\title{
ADHESION OF LEPTOSPIRES TO MOUSE FIBROBLASTS (L929) AND ITS ENHANCEMENT BY SPECIFIC ANTIBODY
}

\author{
T. Vinh, S. Faine and B. Adler \\ Department of Microbiology, Monash University, Wellington Road, Clayton, 3168, \\ Victoria, Australia
}

\begin{abstract}
SUMmary. The adhesion of leptospires (Leptospira interrogans serovar. copenhageni L45) to mouse L-cells was studied by microscopic observations. Within $3 \mathrm{~h}$ of infection of monolayers many leptospires adhered to $95-100 \%$ of the cells, and intracellular leptospires were demonstrated by electron microscopy. No specific site of attachment on the cells or the leptospires was observed. Avirulent or dead leptospires adhered poorly but attachment of the saprophytic leptospire L. biflexa serovar. patoc occurred on cell and glass surfaces. After adhesion, microvilli on the cell surfaces disappeared within $6 \mathrm{~h}$ of infection and cell damage was observed after $12 \mathrm{~h}$. The adhesion was greatly enhanced by the presence of specific antiserum at a subagglutinating concentration. No direct penetration by leptospires of the host cells was observed with transmission and scanning electron microscopy. It appears that (1) adhesion of leptospires to L-cells precedes cell damage, and (2) leptospires may enter cells either through damaged membranes, or by a phagocytosis-like mechanism.
\end{abstract}

\section{INTRODUCTION}

The adhesion of pathogenic bacteria to host-cell membranes appears to be an important, initial mechanism in microbial pathogenicity (Smith, 1977). In natural infections, leptospires survive in the proximal renal tubules of carrier animals, multiplying and colonising the tubular epithelium (Alston and Broom, 1958; Babudieri, 1958) in the presence of small amounts of specific antibody (Faine, 1962 and 1963). In experimental acute infection of hamsters, Miller and Wilson (1967) found large numbers of Leptospira interrogans serovar. pomona closely associated with the microvilli of epithelial cells in the proximal renal tubules, and it has been postulated that the vascular damage and subsequent haemorrhage, which are the main features of acute experimental leptospirosis, may be caused by endotoxin-like (Arean, Sarasin and Green, 1964) or cytotoxic (Yam, Miller and White, 1970; Finn and Jenkin, 1973; Chaperon, Davis and Miller, 1979) factors. 
In studies of the interaction of leptospires and host tissue cells in vitro, the spirochaetes adhered in large numbers to fibroblastic-like, but not to epithelial-like cells (Harrington and Sleight, 1966), followed by the subsequent appearance of a cytopathic effect (CPE) (Miller, Froehling and White, 1970; Finn and Jenkin, 1973) which suggests that the cytopathic factors were closely bound to the leptospiral body (Miller et al., 1970). There is also evidence for penetration of cells by leptospires (Miller and Wilson, 1962, 1967; Faine, Hudson and Frank, 1975). However, these previous studies have described the CPE on the host cells rather than mechanisms of host-leptospire interactions.

In this report, the adhesion of $L$. interrogans serovar. copenhageni (strain L45, virulent for guinea pigs) and L. biflexa serovar. patoc (strain L41) to mouse fibroblasts (L929 cells) and their interactions were investigated by light and electron microscopy.

\section{MATERIALS AND METHODS}

Leptospires. L. interrogans serovar. copenhageni, strain L45 (Faine and van der Hoeden; 1964) was virulent for guinea pigs. A dose of $10^{7}-10^{8}$ leptospires killed young guinea pigs in 3-5 days. The virulence of strain L45 was maintained by regular passages in young guinea pigs weighing $75-90 \mathrm{~g}$. An avirulent straight variant of this strain was isolated from an old culture of the virulent hooked strain and cloned in this laboratory and designated S45. The saprophytic $L$. biflexa serovar. patoc (Patoc 1), strain L41, was obtained from A. D. Alexander, Walter Reed Army Medical Research Center, Washington DC, USA, in 1965. Leptospires were grown in Polysorbate 80-bovine serum albumin medium (EMJH, Difco Laboratories) for 4-7 days at $30^{\circ} \mathrm{C}$ and were counted in a Thoma counting chamber.

Preparation of L-cell monolayers. Monolayers of a mouse fibroblast cell line, L929, obtained from Commonwealth Serum Laboratories, Melbourne, Australia, were grown in tissue-culture

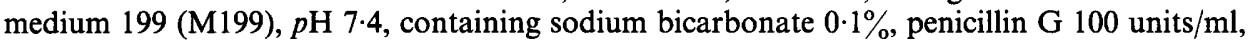
streptomycin sulphate $100 \mu \mathrm{g} / \mathrm{ml}$ and fetal calf serum (fcs) $10 \%$. Cultures were kept at $37^{\circ} \mathrm{C}$ for 7 days with one change of the medium on the third day. The monolayers were then washed with $30 \mathrm{ml}$ of warm Dulbecco's phosphate-buffered saline (PBS, $p \mathrm{H} \mathrm{7.2)}$ without $\mathrm{Ca}^{++}$and $\mathrm{Mg}^{++}$ followed by a brief wash with $5 \mathrm{ml}$ of a solution of Antibiotic-Trypsin-Versene (ATV) containing $\mathrm{NaCl} 8 \mathrm{~g}, \mathrm{KCl} 0.4 \mathrm{~g}$, dextrose $1 \mathrm{~g}, \mathrm{NaHCO}_{3} 0.58 \mathrm{~g}$, trypsin ( 1 in 250$) 0.5 \mathrm{~g}$, Versene (EDTA) $0.2 \mathrm{~g}$, penicillin $\mathrm{G} 100000$ units and streptomycin sulphate $100000 \mu \mathrm{g}$ per $\mathrm{L}$. The monolayers were then treated with $1 \mathrm{ml}$ of ATV solution at $37^{\circ} \mathrm{C}$ for $5-10 \mathrm{~min}$ to remove the cells from the glass.

A cell suspension was prepared containing $c .1 .2 \times 10^{5}$ cells $/ \mathrm{ml}$ in $20 \mathrm{ml}$ of antibiotic-free M199 containing 0.25 $\mathrm{M}$-2-hydroxyethyl-piperazine-N-2ethanesulphonic acid solution $5 \%$ and fcs $5 \%$ and $1 \cdot 2-\mathrm{ml}$ volumes of the suspension were dispensed into Leighton tubes containing $22 \times 8 \mathrm{~mm}$ coverslips. For growing cells in Sykes-Moore chambers (Sykes and Moore, 1960), $0.65-\mathrm{ml}$ volumes of cell suspension were inoculated into the chambers (Bellco Company, USA), which were incubated horizontally at $37^{\circ} \mathrm{C}$ for $18-24 \mathrm{~h}$ in a humidified atmosphere containing $\mathrm{CO}_{2} 5 \%$. After the cell monolayers had become $50-60 \%$ confluent, they were washed with warm PBS to remove unattached cells and were ready for use in adhesion studies. The viability of the cells was assessed by the exclusion of trypan blue.

Coincubation of leptospires and L-cell monolayers. Suspensions of live leptospires from 7-day-old cultures containing $(2-5) \times 10^{8}$ organisms $/ \mathrm{ml}$ in EMJH medium were harvested by centrifugation at $12000 \mathrm{~g}$. The leptospires were washed twice with PBS, and resuspended in antibiotic-free M199 supplemented with $\mathrm{fcs} 5 \%, p \mathrm{H} \mathrm{7.4}$, to a concentration of $2 \times 10^{8}$ organisms $/ \mathrm{ml}$. The leptospiral suspension was added to the L-cell monolayers giving an infectivity ratio of $c .10^{3}$ leptospires/cell. The infected monolayers were incubated at $37^{\circ} \mathrm{C}$ in a humidified atmosphere containing $\mathrm{CO}_{2} 5 \%$ for $3 \mathrm{~h}$. Leptospires killed either by heating at $56^{\circ} \mathrm{C}$ for $30 \mathrm{~min}$ or by treating with formalin (1\% in PBS) for 30 min were resuspended in M199 and inoculated on to L-cell monolayers.

At the end of the experiment, the coverslips containing infected monolayers were washed 
three times with PBS to remove unattached leptospires, fixed with $1 \%$ neutralised formalin for 15 min at room temperature and then stained with silver followed by Haematoxylin and Eosin ( $\mathrm{H} \&$ E) (Faine, 1965), or examined by immunofluorescence.

Indirect immunofluorescence staining. The fixed coverslips were covered with rabbit antiserum against leptospires for $30 \mathrm{~min}$ at $37^{\circ} \mathrm{C}$ in a moist chamber. After incubation, the coverslips were washed for $30 \mathrm{~min}$ in $250 \mathrm{ml}$ of PBS. The monolayers were then covered with a drop of fluorescein-labelled sheep anti-rabbit immunoglobulin (Wellcome, England) and incubated for $30 \mathrm{~min}$ at $37^{\circ} \mathrm{C}$ in a moist chamber. The coverslips were finally washed in $250 \mathrm{ml}$

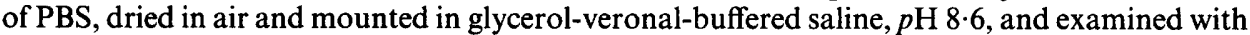
a IM35 Zeiss Microscope equipped with epifluorescence illumination.

$C P E$ on mouse L-cells. The cytopathic effect on L-cell monolayers infected with different strains of leptospires in Leighton tubes was observed every day for 7 days with an Olympus inverted microscope. The degree of the CPE was recorded as 1,2,3 and 4+ corresponding to $25,50,75$ and $100 \%$ cell damage.

Counting of adherent leptospires on L-cell surfaces. The stained preparations were dried in air, mounted on a drop of DPX medium then examined with a Zeiss microscope, using bright field and an oil immersion $\times 100$ objective. The number of adherent leptospires was determined in duplicate preparations by counting 40 cells of the same size at random in each of the coverslips. The average number of adherent leptospires/cell and the standard deviation were calculated.

Phase contrast microscopy. Direct observation of the interaction between L-cells and leptospires was made by phase-contrast microscopy using Wild or Zeiss IM35 inverted microscopes at a magnifications of $\times 400-\times 630$. Micrographs were taken using an electronic flash to eliminate blurring due to leptospiral movement.

Transmission electron microscopy (TEM). Infected monolayers in Falcon plastic flasks were washed three times with warm PBS to remove unattached leptospires. The cells were then fixed in situ with $2.5 \%$ glutaraldehyde (EM grade, Merck) in $0.05 \mathrm{M}$ cacodylate buffer $p \mathrm{H} \mathrm{7.4}$, and then post fixed with $1 \%$ osmium tetroxide for $1 \mathrm{~h}$ at $4^{\circ} \mathrm{C}$. The fixed cells were removed from the plastic surface with a "rubber policeman", dehydrated in graded ethanol, followed by epoxypropane and embedded in Spurr resin.

Thin sections cut with a LKB or Reichert ultratome equipped with glass knives, were mounted on 200-mesh grids, stained with uranyl acetate and lead citrate and examined with a Phillips EM 300 electron microscope at $80 \mathrm{Kv}$.

Scanning electron microscopy (SEM). Infected monolayers in Falcon flasks were fixed in situ with $2.5 \%$ glutaraldehyde in cacodylate buffer $(p \mathrm{H} 7 \cdot 4)$ for $4 \mathrm{~h}$ at $4^{\circ} \mathrm{C}$, washed and dehydrated through a graded series of increasing ethanol concentrations, followed by two further treatments with absolute ethanol each for $30 \mathrm{~min}$, and then two changes of amyl acetate at room temperature, each for $15 \mathrm{~min}$. The bases of plastic flasks containing the treated infected monolayers were cut into small squares and dried in a critical point drying apparatus (Hitachi, Japan) with amyl acetate; the dried squares were attached to aluminium stubs and coated with carbon and gold in a Polaron evaporator with a rotary coater attachment. Samples were observed in a Cambridge Mark 2A scanning electron microscope at $20 \mathrm{Kv}$.

Effect of antisera. Rabbit antisera were prepared by giving New Zealand white rabbits intravenous injections of $5 \mathrm{ml}$ of leptospiral culture grown in Korthof's medium supplemented with $10 \%$ rabbit serum (Adler and Faine, 1978). The agglutination titre was determined by the microscopic agglutination test (MAT) described by Alston and Broom (1958); Cooke Microtitre equipment was used to prepare serum dilutions.

The effect of antisera on the adhesion of leptospires to mouse L-cells was examined by incubating leptospires with rabbit antiserum diluted one in 1000 (subagglutinating titre) for 30

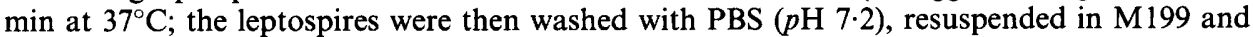
centrifuged at $450 \mathrm{~g}$ to separate any clumps. The number of antibody-coated leptospires in the supernate was adjusted to $2 \times 10^{8}$ organisms $/ \mathrm{ml}$ and $1-\mathrm{ml}$ volumes added to L-cell monolayers. In another experiment, antiserum was added to the leptospiral suspension in M199 which was inoculated on to L-cell monolayers. At the end of each experiment the coverslips containing infected monolayers were washed, and processed for staining and counting as described above. The mean number of adherent leptospires/cell was calculated by counting 40 cells and the results 
were expressed as a percentage of the control values (mean number of untreated leptospires/untreated cell incubated at $37^{\circ} \mathrm{C}$ for $3 \mathrm{~h}$ ) which were regarded as $100 \% \pm$ standard deviation.

To determine whether immunoglobulins bound to L-cell membranes via their Fc portions, the cell monolayers were treated with anti-leptospire serum then with fluorescein-conjugated sheep anti-rabbit immunoglobulins (Wellcome, England). The preparations were observed with a IM35 Zeiss microscope equipped with epifluorescence illumination.

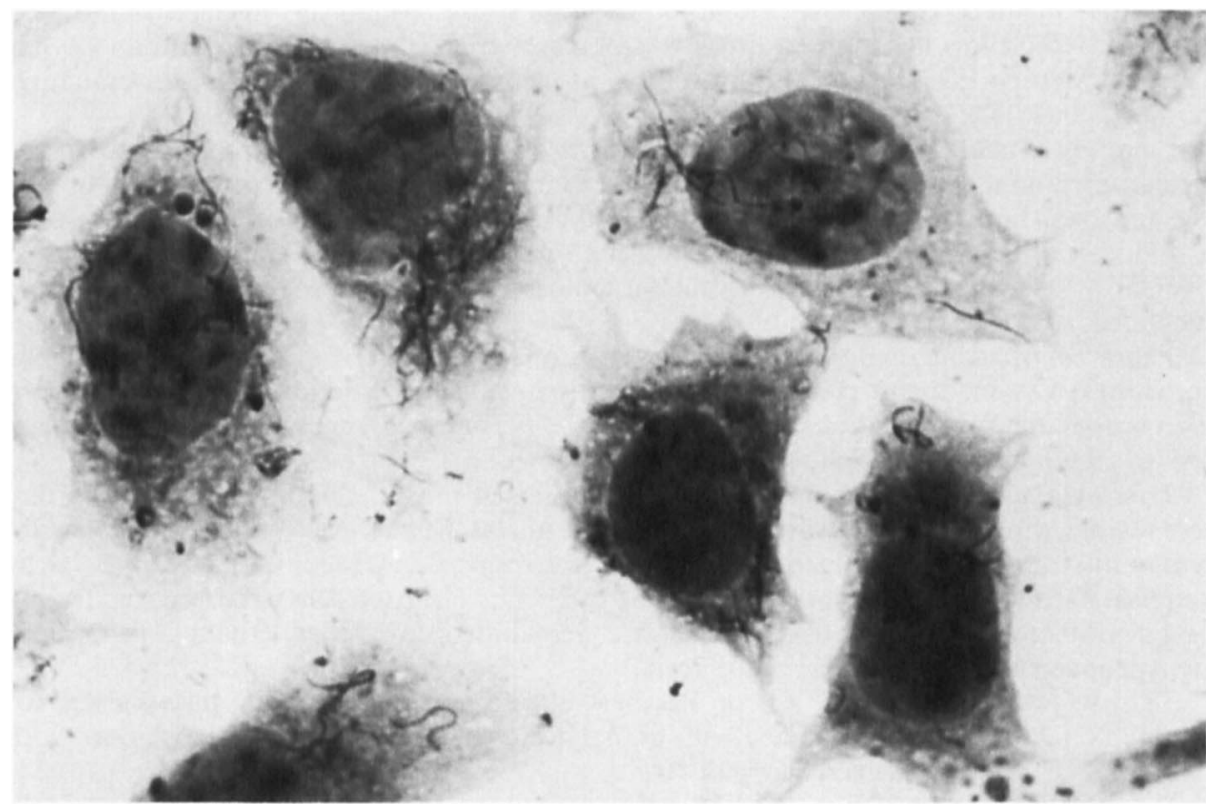

FIG. 1.-Adhesion of leptospires (strain L45) to L-cell surface $3 \mathrm{~h}$ after infection. Silver stain followed by Haematoxylin and Eosin $(\times 800)$.

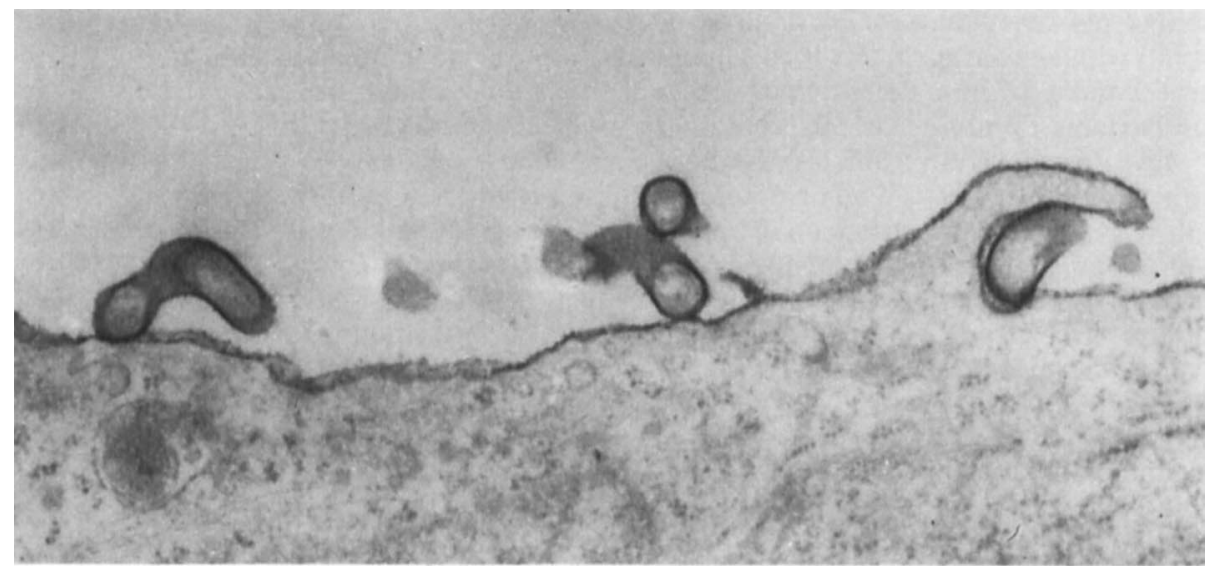

FIG. 2.-Electron micrograph showing leptospires (strain L45) closely associated with L-cell membrane $3 \mathrm{~h}$ after infection. Uranyl acetate and lead citrate post stain $(\times 16000)$. 


\section{RESULTS}

\section{Phase-contrast and bright field microscopy}

Immediately after being added to L-cell monolayers grown in Sykes-Moore chambers, leptospires of either virulent strain L45 or saprophytic strain L41 came close to the cell surface. Within $10 \mathrm{~min}$ they adhered end-on to the cell surface while retaining their motility; $3 \mathrm{~h}$ after infection, 5-25 leptospires adhered to the surface of each of $90-100 \%$ of the cells, in some cases by their ends and in others by their whole length. The ability to count adherent leptospires accurately was limited by leptospiral

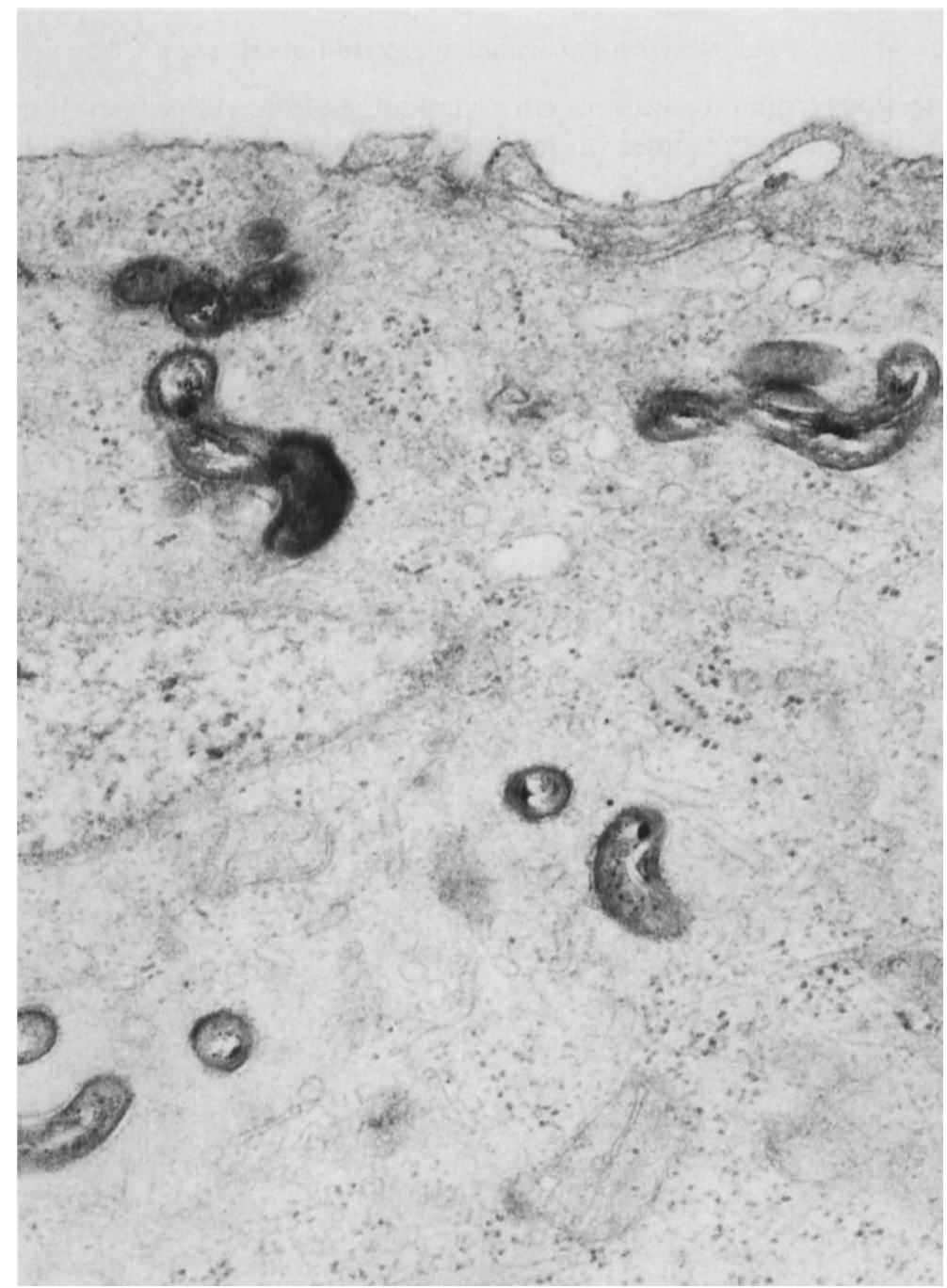

FIG. 3.-Electron micrograph showing intracellular leptospires (strain L45) $3 \mathrm{~h}$ after infection. Uranyl acetate and lead citrate post stain $(\times 20000)$. 
motility and depth of focus. Leptospires could be seen "snaking" or "crawling" on the cell surface and, from time to time, moving away from the cell, indicating that they retained their motility in the liquid medium. Other leptospires moved in circular motion and finally rounded up on the cell surface. Fewer avirulent (S45) than virulent (L45) and saprophytic (L41) leptospires adhered to the host cells, of which only $10-20 \%$ had $1-3$ avirulent leptospires associated with their surfaces $3 \mathrm{~h}$ after infection. No further adhesion was observed with any of the strains after $3 \mathrm{~h}$. When infected monolayers were washed to remove unattached leptospires, fixed and stained with silver nitrate and $\mathrm{H} \& \mathrm{E}$, leptospires of strain L45 were seen to adhere only on the cell surfaces (fig. 1) whereas those of strain L41 adhered on both the cell and the glass surfaces, indicating a non-specific adhesion to the latter. Heated or formalin-killed leptospires of all three strains adhered poorly to L-cells (1-2 per cell).

\section{Transmission and scanning electron microscopy}

Thin sections from preparations corresponding to different periods of incubation showed that leptospires of either virulent strain L45 or saprophytic strain L41 adhered

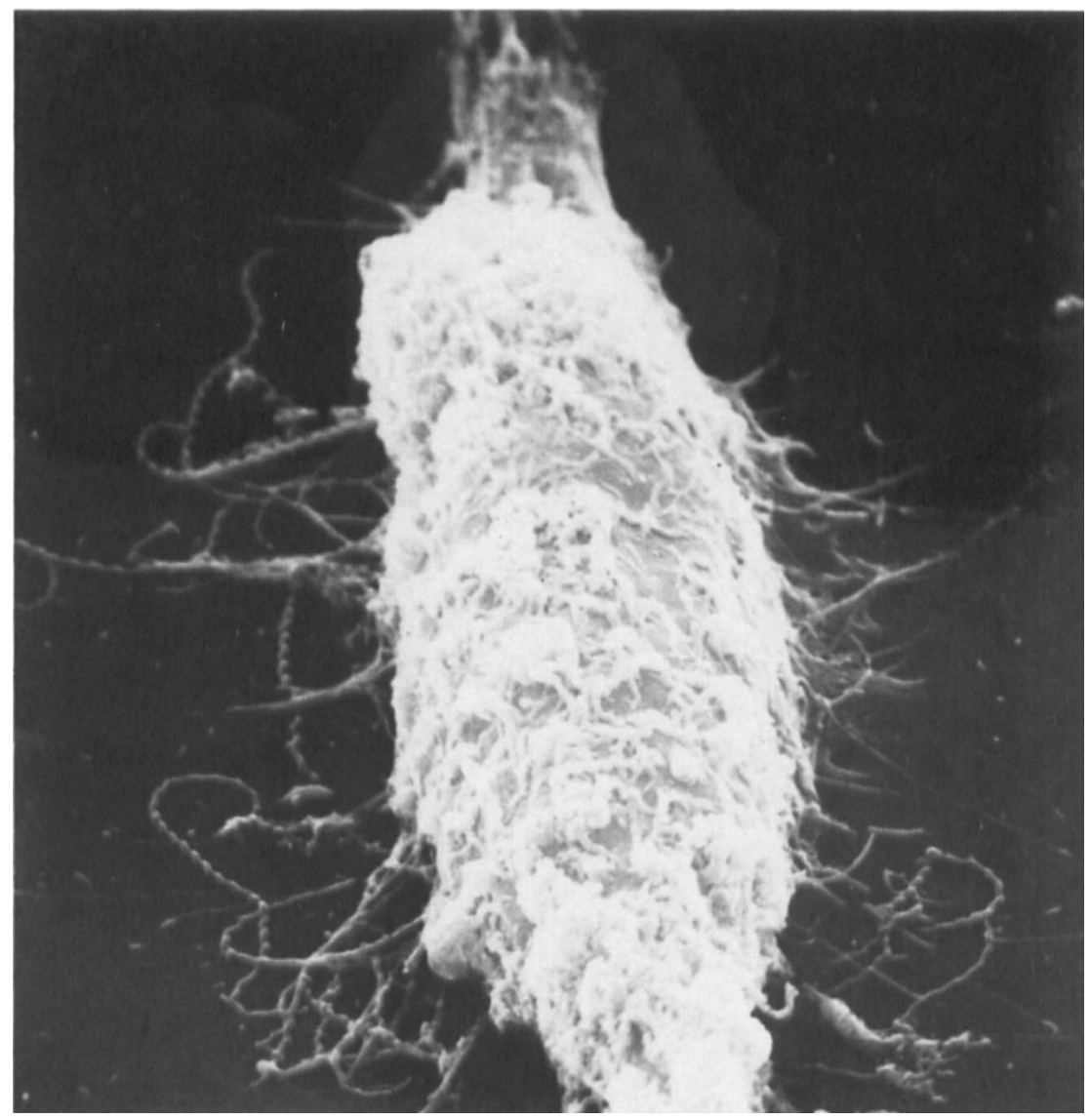

FIG. 4.- Scanning electron micrograph $1 \mathrm{~h}$ after infection showing leptospires (strain L45) adherent end-on around the cell periphery and few leptospires on the cell surface among microvilli $(\times 4000)$. 
to the surface membranes of L-cells either by one end or by a portion of their length. Sometimes leptospires were overlapped by a protrusion of the cell surface (fig. 2 ). Leptospires were seen intracellularly within $2 \mathrm{~h}$ of infection; no intracellular leptospires were observed in earlier stages of the infection, and after $3 \mathrm{~h}$ morphologically intact leptospires could be seen in the cytoplasmic vacuoles (fig. 3). Some leptospires were observed close to the nuclear membrane but never free within the cytoplasm or within nuclei. Avirulent leptospires (S45) were rarely seen adherent to the cell and were never seen intracellularly.

Scanning electron micrographs showed that uninfected fibroblasts were attached to the plastic surface by long and rigid filipodia and the cell surface was covered with cylindrical, unbranched finger-tipped microvilli. Leptospires were easily distinguished from microvilli and filipodia by their spiral (undulated) shape. Ten min after infection, they were seen to surround the cells, either adhering to the cell edge or lying on the cell surface between microvilli (fig. 4). Leptospires adhered to the host cells by anchoring to the cell by their ends and occasionally associating with microvilli.

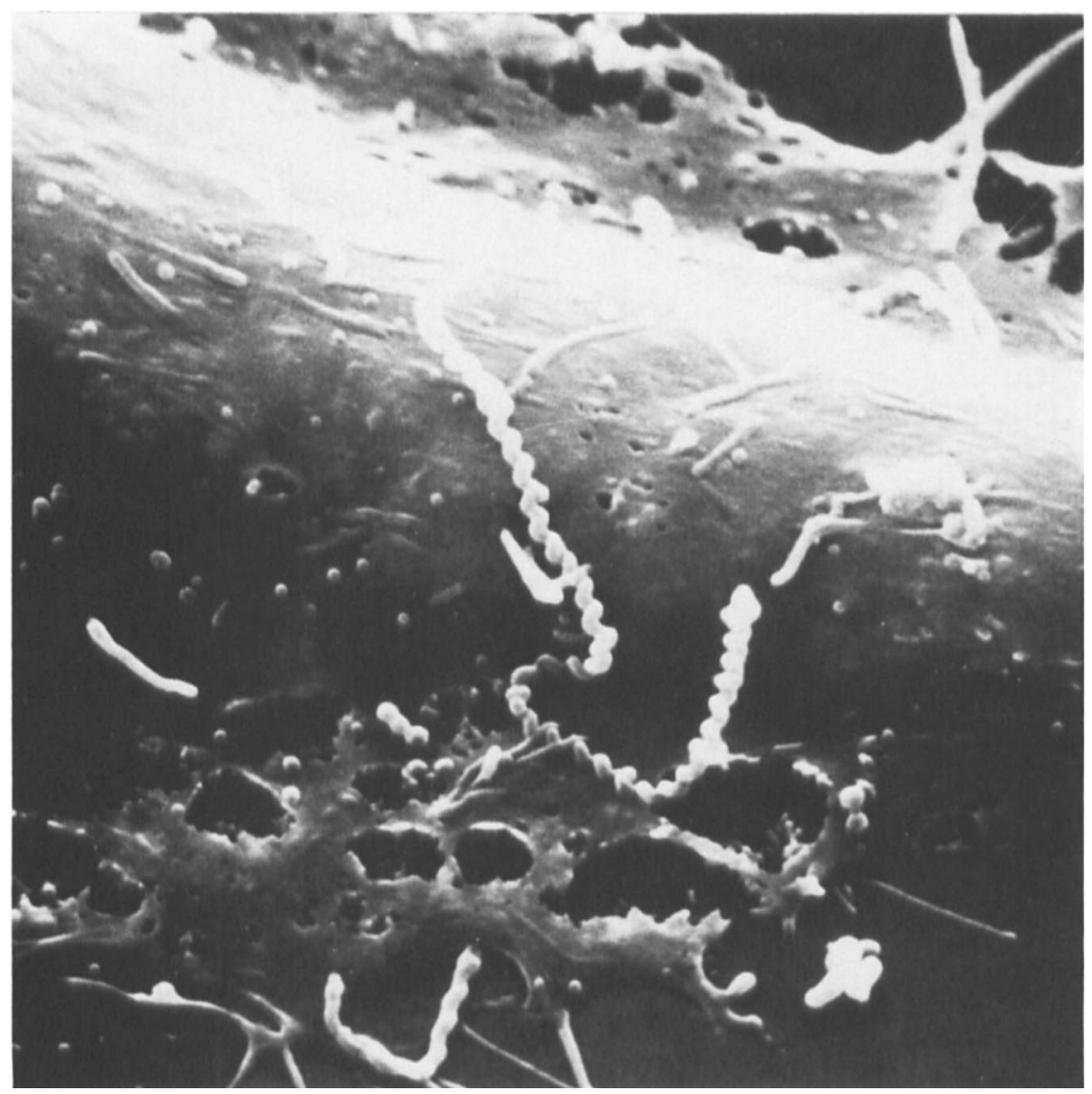

FIG. 5.-Scanning electron micrograph showing an L-cell partially damaged with pits and holes $6 \mathrm{~h}$ after infection; most microvilli have disappeared from the cell surface. A leptospire is seen adherent to the cell surface $(\times 8000)$. 
Fewer microvilli were seen on the cell surface $3 \mathrm{~h}$ after infection and after $6 \mathrm{~h}$ only a few short microvilli remained on a smooth surface, with few leptospires lying across it, and irregular perforations were seen on the surfaces (fig. 5). Three days after infection masses of leptospires were adherent to each other and to cells that had lost their microvilli. From 12 to $24 \mathrm{~h}$ after infection, the cells appeared swollen and had large crater-like holes (fig. 6). The monolayer lost its intercellular adhesion and cells became round and broken. Control uninfected monolayers remained normal throughout the experimental period. The infection of $\mathrm{L}$ cells with the strain $\mathrm{S} 45$ and the saprophytic strain L41 was not examined by SEM.

\section{Effect of antiserum}

Homologous but not heterologous antiserum enhanced the adhesion of leptospires to mouse fibroblasts, whether it was added to the medium (data not shown) or used to pretreat leptospires before infecting the host cells (table I). The addition of normal rabbit serum did not affect adhesion. The effect of antiserum on the adhesion of avirulent strain S45 was not investigated. A possible explanation for these

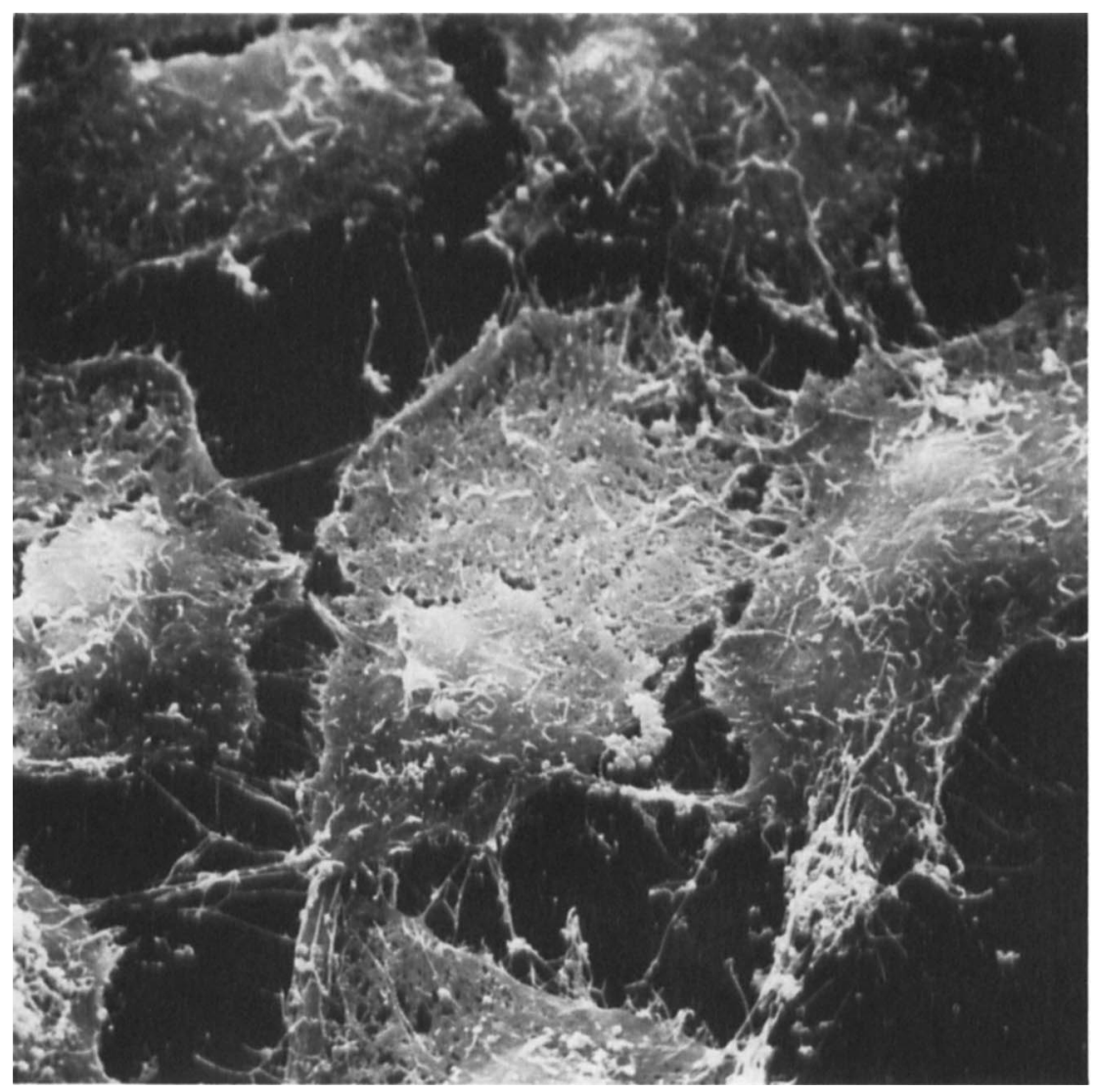

FIG. 6.-Scanning electron micrograph showing a damaged cell monolayer with few leptospires adherent to the cell surfaces $24 \mathrm{~h}$ after infection $(\times 1600)$. 
TABLE I

Effect of normal or immune rabbit sera on the adhesion of leptospires of serovars copenhageni (strain L45) and biflexa patoc (strain L41) to L-cell monolayers

\begin{tabular}{|c|c|c|}
\hline Leptospire & $\begin{array}{l}\text { Treatment with } \\
\text { stated serum }\end{array}$ & $\begin{array}{l}\text { Percentage of adherent } \\
\text { leptospires per cell } \pm S D \\
\quad(\text { control }=100)\end{array}$ \\
\hline $\begin{array}{l}\text { L. interrogans } \\
\quad \text { serovar. copenhageni }\end{array}$ & $\begin{array}{l}\text { none (control) } \\
\text { homologous antiserum } \\
\text { heterologous antiserum (against } \\
\text { L. biflexa serovar. patoc) } \\
\text { normal rabbit serum }\end{array}$ & $\begin{array}{l}100 \pm 5 \\
150 \pm 15 \\
90 \pm 5 \\
95 \pm 5\end{array}$ \\
\hline $\begin{array}{l}\text { L. biflexa } \\
\quad \text { serovar. patoc }\end{array}$ & $\begin{array}{l}\text { none (control) } \\
\text { homologous antiserum } \\
\text { heterologous antiserum (against } \\
\text { serovar. copenhageni) } \\
\text { normal rabbit serum }\end{array}$ & $\begin{array}{l}100 \pm 10 \\
180 \pm 15 \\
100 \pm 5 \\
100 \pm 5\end{array}$ \\
\hline
\end{tabular}

observations may have been that L-cell fibroblasts shared a common antigen with leptospires or possessed a receptor for the Fc region of the immunoglobulin molecule. L-cells were therefore treated with anti-L45 antiserum then with fluorescein-conjugated sheep anti-rabbit immunoglobulins. However, no fluorescence was observed, whereas leptospires treated with these reagents fluoresced brightly.

TABLE II

Cytopathic effect (CPE) on mouse fibroblasts (L929) of virulent (L45), avirulent (S45) and saprophytic (L41) leptospires

\begin{tabular}{l|cccccccc}
\hline & \multicolumn{8}{|c}{ CPE on mouse fibroblasts at day } \\
\cline { 2 - 8 } Strain & 1 & 2 & 3 & 4 & 5 & 6 & 7 & days \\
\hline L45 & - & - & $1+$ & $1+$ & $2+$ & $3+$ & $4+$ & \\
S45 & - & - & - & - & - & - & - & \\
L41 & - & $1+$ & $2+$ & $3+$ & $4+$ & $4+$ & $4+$ \\
\hline
\end{tabular}

$-=$ No CPE; $1-4+=$ degree of CPE observed corresponding to $25-100 \%$ cell destruction.

Cytopathic effect (CPE) on mouse fibroblasts (L929)

Light microscopic observation of the cytopathic effect of different strains of leptospires on mouse L-cell monolayers is shown in table II. An inoculum of $2 \times 10^{8}$ organisms $/ \mathrm{ml}$ (infective dose of $10^{3}$ leptospires/cell) caused degeneration of the L-cell monolayers on the third day after infection with virulent strain L45, and on the first day after infection with saprophytic strain L41. The early CPE observed with strain L41 may have been accounted for by the large number of leptospires adherent to the L-cells. 


\section{Discussion}

Although many investigations in vivo and in vitro have suggested that toxic factors were the most likely cause of host-tissue damage by leptospires, nothing is known of the contribution made by the adhesion of leptospires to host cells towards the establishment of either acute infection or of the carrier state in the host. At present, the persistence of pathogenic leptospires in the kidney tubules of animal carriers is not fully understood. However, these spirochaetes must be able to adhere to and colonise the tubular epithelial surface, having survived the killing effect of the host's immunological and bactericidal defences. Tissue culture is a useful model to study the molecular basis of host and parasite interactions, because it is independent of host immunological interference, although the conditions in vitro may not necessarily reflect those in vivo.

This work was undertaken in an attempt to elucidate the interaction between leptospires and tissue culture cells (L929 cell line) in vitro by light and electron microscopy observations.

As soon as they were inoculated on to the monolayers, leptospires readily adhered to L-cell surfaces either by their ends anchoring to the cell edges, by their whole length on the cell surface, or by association with microvilli, suggesting there was no preferred site of attachment either on the cell or the leptospire. Virulent leptospires (L45) adhered in much greater numbers than avirulent ones (S45), whereas saprophytic leptospires (L41) adhered non-specifically to cell and glass surfaces. The ability of virulent and saprophytic leptospires to adhere to the host cells may account for cytotoxicity. Indeed, either saprophytic or virulent leptospires were able to damage L-cell monolayers. These observations were in agreement with those of Finn and Jenkin (1973) who demonstrated the cytopathic effects of Leptospira serovars. patoc and canicola in kidney cell culture. While attached end-on to the host cells, leptospires retained their motility; those flat on the cell surface lost their rapid spinning motion, but were able to crawl or snake on the surface, similar to the observations described by Cox and Twigg (1974) on the movement of L. interrogans (serovar. icterohaemorrhagiae strain $3 \mathrm{H}$ ) in semi-solid medium. This restriction of leptospiral movement may be due to the 'fluidity' or 'viscosity' of the lipid bilayer on the host-cell membrane (Shinitzky and Inbar, 1976). It is also possible that the microvilli may restrict the movement of spirochaetes once they touch the host cell surface.

Avirulent straight leptospires, which are less motile (Faine and van der Hoeden, 1964), and heat- or formalin-killed virulent or saprophytic leptospires did not adhere significantly to the host cells, suggesting that functional physiological activity of these spirochaetes was necessary for attachment and that an intact outer envelope was necessary for adhesion. Indeed, leptospiral motility may facilitate contact between the two surfaces.

The decrease in number and subsequent disappearance of microvilli on L-cell surfaces followed by cell damage may be due to a toxic effect of motile leptospires. Disappearance of microvilli leading to cell damage has been reported in kidneys and livers from animals experimentally infected with $L$. icterohaemorrhagiae (De Brito et al., 1966; De Brito, Bohm and Yasuda, 1979). Furthermore, the degeneration of the renal tubular brush-border was seen to be associated with close proximity of leptospires (Marshall, 1974). 
It is not known whether the pits and holes observed in scanning electron micrographs was due to a 'toxin' or to the active role of motile leptospires. In either case, the results would be leakage of cytoplasmic material leading to cell death. However, it is also possible that leptospires penetrated cells already damaged by 'toxin' (Marshall, 1974). The cell damage was observed much earlier by electron microscopy than by light microscopy where the CPE could only be detected $24 \mathrm{~h}$ after infection. Intracellular leptospires, mostly within the cell vacuoles, were observed in thin sections $2-3 \mathrm{~h}$ after infection of the monolayers.

The fact that leptospires were seen surrounded by a cell protrusion and their round form observed with phase contrast at an early stage in infection would suggest that leptospires may enter the host cell by a phagocytosis-like mechanism, similar to the ingestion of polystyrene latex particles or chlamydial species by these non-professional phagocytes (Byrne and Moulder, 1978). Rose, Eveland and Ellinghausen (1966) suggested that $L$. interrogans serovar. pomona actively penetrated kidney cells, but their evidence was not conclusive. Another possibility is that leptospires may enter the cells through damaged cell membranes. If this is so, it would confirm the observations of Marshall (1974).

The mechanism by which homologous specific immune serum enhances leptospiral adhesion to the host cell surfaces is not clear. Because heat-inactivated antisera were used, their enhancing effect on the adhesion was not complement-dependent in contrast to the immune-adherence of leptospiral antigens to human red blood cells (Linscott and Boak, 1961). Attempts to demonstrate a common antigen or, possibly, a receptor for the $\mathrm{Fc}$ region of the immunoglobulin molecule on L-cell membrane surfaces using fluorescein-conjugated anti-rabbit immunoglobulin to stain L-cells preincubated with normal or immune rabbit serum were unsuccessful, although it has been suggested that a common antigen exists between cultured mouse cells and certain gram-negative bacteria (Fedoroff and Webb, 1962; Rowley and Jenkin, 1962) and between leptospires and other microorganisms (Rothstein, 1957). Normal rabbit serum did not have any effect on the adhesion. The coating of immune serum on the leptospiral surface may render it more hydrophobic thus promoting close contact to the host cell membrane as suggested by van Oss (1978) in a study of the adhesion of opsonised bacteria to phagocytic cells. The enhancement of bacterial adhesion to the host cell by specific antibodies was also demonstrated by Hale and Bonventre (1979) for Shigella flexneri $2 \mathrm{a}$.

In contrast to the present results with leptospires, other workers have reported an inhibitory effect of immune serum on attachment of other bacteria to tissue cells. Homologous antisera prevented the adhesion of Bordetella pertussis to human fibroblasts (Holt, 1972) and convalescent rabbit immune serum blocked the adhesion of Treponema pallidum to cultured rabbit testicular cells (Fitzgerald et al., 1977).

In conclusion, leptospires have been shown to adhere and possibly to cause damage to mouse L-cells. The adhesion was enhanced by specific antibody. Leptospires probably enter these cells through damaged membranes or by a phagocytosis-like mechanism.

This work was supported by grants from Monash University and the National Health and Medical Research Council, Canberra, Australia.

We thank Associate Professor E. F. Glasgow, Department of Anatomy, Monash University, 
for permission to use that department's facilities and equipment for scanning electron microscopic studies. We also acknowledge the excellent technical assistance of Joselyn Brittingham, Dianne Jessup and Khim Hoe

\section{REFERENCES}

Adler B, Faine S 1978 Serological and protective-antibody responses of rabbits to leptospiral antigens. Journal of Medical Microbiology 11:401-409.

Alston M J, Broom J C 1958 Leptospirosis in man and animals. Livingstone, Edinburgh.

Arean M V, Sarasin G, Green J H 1964 The pathogenesis of leptospirosis: Toxin production by leptospira icterohaemorrhagiae. American Journal of Veterinary Research 25:836-843.

Babudieri B 1958 Animal reservoirs of leptospires. Annals of the New York Academy of Science 70:393-413.

Byrne G I, Moulder J W 1978 Parasite-specified phagocytosis of Chlamydia psittaci and Chlamydia trachomatis by $\mathrm{L}$ and Hela cells. Infection and Immunity 19:598-606.

Chaperon K M, Davis R B, Miller N G 1979 Effect of a plasma cytotoxic factor in leptospirosis on platelets in vivo. Thrombosis Research 14: 975-980.

Cox P J, Twigg G I 1974 Leptospiral motility. Nature (London), 250:260-261.

DeBrito T, Freymuller E, Hoshino S, Penna D O 1966 Pathology of the kidney and liver in the experimental leptospirosis of the guinea pig. A light and electron microscopy study. Virchows Archiv Pathologische Anatomie 341:64-78.

DeBrito T, Bohm G M, Yasuda P H 1979 Vascular damage in acute experimental leptospirosis of the guinea pig. Journal of Pathology 128:177-182.

Faine S 1962 Factors affecting the development of the carrier state in leptospirosis. Journal of Hygiene 60:427-434.

Faine S 1963 Antibody in the renal tubules and urine of mice. Australian Journal of Experimental Biology and Medical Science 41:81-91.

Faine S 1965 Silver staining of spirochaetes in single tissue sections. Journal of Clinical Pathology 18:381-382.

Faine S, Hudson R E, Frank R 1975 Pathogenic mechanisms in leptospirosis. Cytopathic effects. In Proceedings of the National Symposium on Leptospirosis, Leptospira and other Spirochaeta-Bucharest, September 25-27, 1975, Editura Medicara, Bucharest, Romania, 145-149.

Faine S, van der Hoeden J 1964 Virulence-linked colonial and morphological variation in Leptospira. Journal of Bacteriology 88:1493-1496.

Fedoroff S, Webb S J 1962 Natural cytotoxic antibodies in human blood sera which react with mammalian cells and bacteria. Nature (London), 193:80-81.

Finn M A, Jenkin H M 1973 Cytopathic effects of Leptospira serotypes patoc and canicola in three kidney cell culture systems. American Journal of Veterinary Research 34:669-672.

Fitzgerald T J, Johnson R C, Miller J N, Sykes J A 1977 Characterization of the attachment of Treponema pallidum (Nichols strain) to cultured mammalian cells and the potential relationship of attachment to pathogenicity. Infection and Immunity 18:467-478.

Hale T L, Bonventre P F 1979 Shigella infection of Henle intestinal epithelial cells: role of the bacterium. Infection and Immunity 24:879-886.

Harrington D D, Sleight S D 1966 Leptospira pomona in tissue culture: Preliminary study. American Journal of Veterinary Research 27:249-256.

Holt L B 1972 The pathology and immunology of Bordetella pertussis infection. Journal of Medical Microbiology 5:407-424.

Linscott W D, Boak R A 1961 Immune adherence with Leptospira antigens. I. Studies on the immune-adherence phenomenon. Journal of Immunology 86:471-479.

Marshall R B 1974 Ultrastructural changes in renal tubules of sheep following experimental infections with Leptospira interrogans serotype pomona. Journal of Medical Microbiology 7:505-508.

Miller N G, Froehling R C, White R J 1970 Activity of leptospires and their products on L cell monolayers. American Journal of Veterinary Research 31:371-377. 
Miller N G, Wilson R B 1962 In vivo and in vitro observations of Leptospira pomona by electron microscopy. Journal of Bacteriology 84:569-576.

Miller N G, Wilson R B 1967 Electron microscopic study of the relationship of Leptospira pomona to the renal tubules of the hamster during acute and chronic leptospirosis. American Journal of Veterinary Research 28:225-235.

Rose G W, Eveland W C, Ellinghausen H C 1966 Mechanisms of tissue cell penetration by Leptospira pomona: Active penetration studies in vitro. American Journal of Veterinary Research 27:1461-1471.

Rowley D, Jenkin C R 1962 Antigenic cross-reaction between host and parasite as a possible cause of pathogenicity. Nature (London), 193:151-154.

Rothstein N 1957 Studies of the immunochemistry of leptospires. II. Heterogenetic relationship between leptospires and other microorganisms. Journal of Immunology 79:276-280.

Shinitzky M, Inbar M 1976 Microviscosity parameters and protein mobility in biological membranes. Biochemica et Biophysica Acta 433:133-149.

Smith H 1977 Microbial surfaces in relation to pathogenicity. Bacteriological Reviews 41:475-500.

Sykes J A, Moore E B 1960 A simple tissue culture chamber. Texas Reports on Biology and Medicine 18:288-297.

van Oss C J 1978 Phagocytosis as a surface phenomenon. Annual Review of Microbiology 32:19-39.

Yam P A, Miller N G, White R J 1970 A leptospiral factor producing a cytopathic effect on L cells. Journal of Infectious Diseases 122:310-317. 